\title{
GROWTH AND PRODUCTIVITY OF COWPEA FERTILIZED WITH BIODIGESTER SEPTIC TANK EFFLUENT
}

\author{
BORGES, Paulo Rogério Siriano ${ }^{1}$ \\ SABOYA, Rita de Cassia Cunha ${ }^{2}$ \\ SIEBENEICHLER, Susana Cristine ${ }^{3}$ \\ SANTOS, Elonha Rodrigues dos ${ }^{4}$ \\ SABOYA, Luciano Marcelo Fallé ${ }^{5}$
}

\begin{abstract}
SUMMARY: This study aimed to evaluate the growth and grain yield of cowpea fertilized with effluent from a biodigester septic tank. The experiment was conducted from March to June 2009 in the municipality of Gurupi, Tocantins State, Brazil. The experiment used a randomized block design, with five treatments and four replicates. Four treatments with fertilizer applications of effluent from a biodigester septic tank (T20 with $20 \mathrm{~mm}$ effluent, T16 with $16 \mathrm{~mm}$ effluent, T12 with $12 \mathrm{~mm}$ effluent, and T8 with $8 \mathrm{~mm}$ effluent), plus a control with NPK fertilizer were tested. The following parameters were determined in the growth analysis: dry weight, leaf area, leaf area index, absolute growth rate, relative growth rate, and net assimilation rate. Agronomic variables related to grain yield and the Pearson correlation between the random variables were also determined. Increasing the dose of the effluent from the biodigester septic tank reduced the performance of the variables related to growth analysis and grain yield. The 8$\mathrm{mm}$ effluent dose resulted in cowpea productivity similar to that obtained with the NPK fertilizer recommended for the crop.
\end{abstract}

Keywords: Vigna unguiculata (L.) Walp. Growth analysis. Waste products.

\section{CRESCIMENTO E PRODUTIVIDADE DE CAUPI ADUBADO COM EFLUENTE DE FOSSA SÉPTICA BIODIGESTORA}

RESUMO: O objetivo desse trabalho foi avaliar o crescimento e rendimento de grãos de caupi adubadas com efluente de fossa séptica biodigestora. O experimento foi conduzido no período de março a junho de 2009 , no município de Gurupi, estado do Tocantins. O delineamento experimental foi de blocos casualizados, com cinco tratamentos e quatro repetições. Foram testados quatro tratamentos com adubações de efluente de fossa séptica biodigestoras (T20 com $20 \mathrm{~mm}$ efluente; T16 com $16 \mathrm{~mm}$ de efluente; T12 com $12 \mathrm{~mm}$ de efluente e T8 com $8 \mathrm{~mm}$ de efluente) mais uma testemunha com adubação NPK. Na análise de crescimento foram determinadas: a massa seca, área foliar, índice de área foliar, taxa de crescimento absoluto, taxa de crescimento relativo e taxa de assimilação líquida. Também foram determinadas variáveis agronômicas relacionadas ao rendimento de grãos, bem como a correlação de Pearson entre as variáveis aleatórias. O aumento da dose de efluente de fossa séptica biodigestora reduz o desempenho das variáveis relativas à análise de crescimento e rendimento de grãos. A dose de $8 \mathrm{~mm}$ de efluente proporciona produtividade de caupi igual a adubação NPK recomendada a cultura.

Palavras chave: Vigna unguiculata (L.) Walp. Análise de crescimento. Resíduos.

\section{INTRODUCTION}

Increased population, urbanization, agricultural expansion, and worldwide industrialization,

\footnotetext{
${ }^{1}$ Faculdades Integradas Aparício Carvalho - FIMCA

${ }^{2}$ EMBRAPA Produtos e Mercado, Campina Grande, PB, Brazil.

${ }^{3}$ Federal University of Tocantins, Gurupi, TO, Brazil.

${ }_{5}^{4}$ Faculdade da Amazônia (FAMA)
} 
combined with the absence of adequate water resource management policies, leads to a scarcity of potable water to meet basic needs, especially in underdeveloped countries. A solution to this problem is the reuse of low-quality water for other activities, such a agriculture, thus avoiding the release of effluents into water bodies and the consequent environmental disequilibrium (BLUM, MELFI and MONTES, 2012; DUARTE et al., 2008; NOBRE et al., 2010; SOUSA NETO et al., 2006; SOUZA NETO et al., 2012).

Rudimentary tanks, or black water tanks, are still very common on small farms. This practice can contaminate groundwater, and well water used for human consumption contains a proliferation of diseasecausing microorganisms (DUARTE et al., 2008). A solution to this problem is the use of biodigester septic tanks that eliminate all pathogenic agents in the waste via enzymatic, acid, and methanogenic hydrolysis, which can reduce the effluent's fecal coliform level to approximately $3 / 100 \mathrm{ml}$. This value is well below that required for class 2 water used to irrigate fruit and vegetables according to the CONAMA Resolution No. 20 of 1986 (1000/100 ml) (NOVAES et al., 2002; OLSEN; LARSEN, 1987).

The recycling of waste for reuse in agriculture has been investigated with residues from various sources, such as tannery sludge, well-drilling waste products, saline wastewater, wastewater from treated domestic sewage, and cattle manure; one of the crops on which the effects of these residues has been studied is the cowpea (Vigna unguiculata (L.) (OLIVEIRA et al., 2001; REBOUÇAS et al., 2010; SILVA et al., 2009; TEIXEIRA et al., 2006). The study of the effects of these waste products aims to extend the useful life of captured water, thus increasing its life and returning it back to the environment in the least impactful way possible. Furthermore, these treatments improve the physical, chemical, and microbial soil properties (DUARTE et al., 2008; GLOAGUEN, 2007; SOUSA et al., 2006; VIEIRA, CASTILHOS and CASTILHOS, 2012).

Cowpea is an important crop in many countries; it grows well in a wide range of environments between latitudes $40^{\circ} \mathrm{N}$ and $30^{\circ} \mathrm{S}$ and adapts to both highlands and lowlands, as well as to acidic soils, aluminum toxicity, and water deficits, which are common problems in soil from Brazilian Cerrado biome (SAN JOSÉ et al, 2004; ZILLI et al., 2011).

In Tocantins State, Brazil, the cowpea is a traditional crop mainly in family-based farming; however, it is becoming increasingly important as a second-harvest crop, grown in rotation with traditional crops. Recently, several studies have addressed the various aspects related to cowpea growth and development under the edaphoclimatic conditions of Tocantins State, Brazil (BORGES et al., 2012; CHAGAS JUNIOR et al., 2010; SANTOS et al., 2011; SILVA et al., 2011). These studies have shown the ability of the plant to adapt to adverse environmental conditions with little loss of productivity, which indicates that cowpea is a crop with high potential for economic growth in Tocantins State.

The use of effluents from biodigester septic tanks is a viable alternative for small-scale farmers because it can be implemented at low cost, promotes the reuse of both macro- and micronutrients by plants, and provides organic matter for the soil (NOVAES et al., 2002; SIMONETE et al., 2003). Growth analysis is an essential tool to study the effects of biodigester tank effluents on cowpea growth and development, because it describes the changes in plant matter production with time, which is not possible based solely on grain yield records (LOPES et al., 2009). Therefore, this study aimed to evaluate growth and grain yield of cowpea plants fertilized with different doses of effluent from biodigester septic tanks.

\section{MATERIAL AND METHOD}

The experiment was conducted from march to june 2009, in Gurupi/TO, Brazil, located at $11^{\circ} 43^{\prime} \mathrm{S}$ and $49^{\circ} 04^{\prime} \mathrm{W}$ and at an altitude of $280 \mathrm{~m}$ asl. The local climate is Aw type (wet with moderate water deficit), according to the Thornthwaite method. Data for the prevailing climate at the time of the 
experiment are shown in Figure 1.

Figure 1. Mean daily temperature values $\left({ }^{\circ} \mathrm{C}\right)$, total daily rainfall values $(\mathrm{mm})$, and mean daily relative humidity values (\%) from march 15 to june 28, 2009, Gurupi/TO, Brazil.

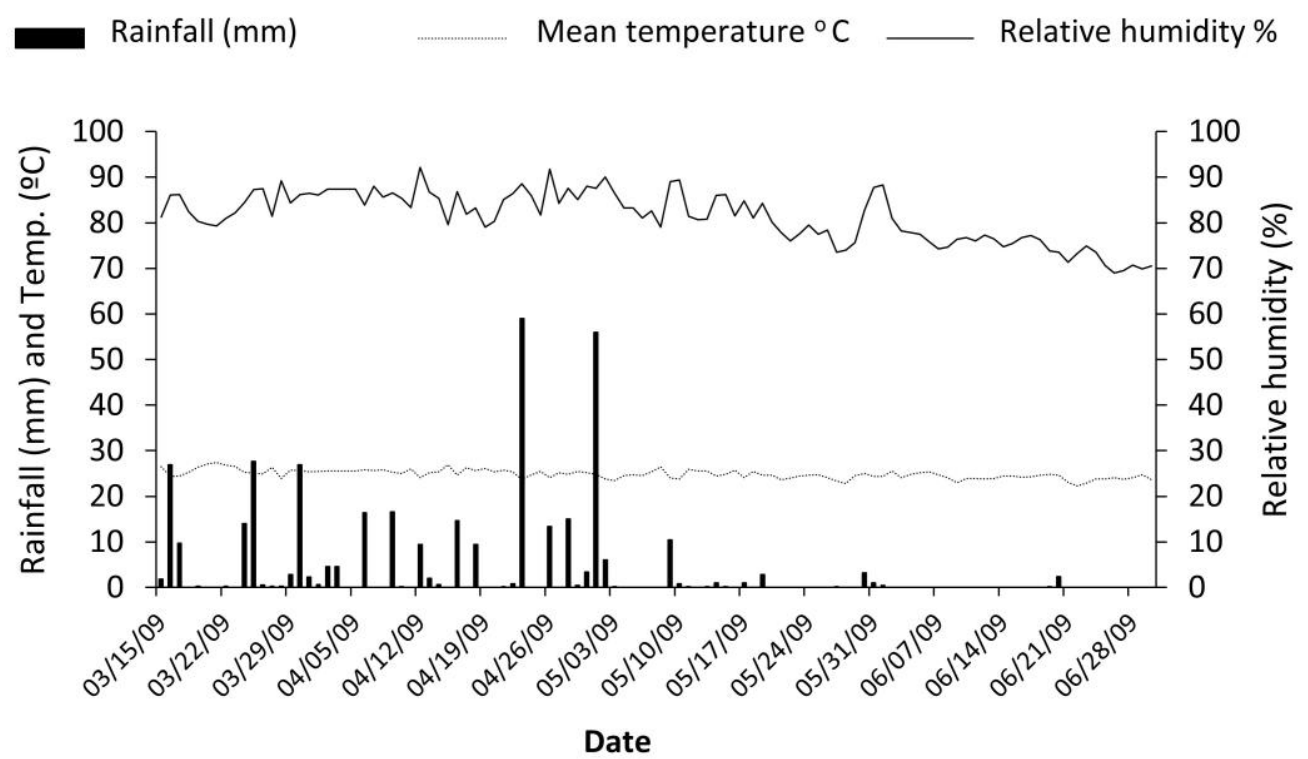

The soil was characterized as dystrophic Red Yellow Latosol, with mean texture and the following characteristics: $0.7 \mathrm{cmol} \cdot \mathrm{dm}^{-3} \mathrm{Ca} ; 0.4 \mathrm{cmol} \cdot \mathrm{dm}^{-3} \mathrm{Mg} ; 0.1 \mathrm{cmol} \cdot \mathrm{dm}^{-3} \mathrm{Al} ; 10.5 \mathrm{mg} \cdot \mathrm{dm}^{-3} \mathrm{~K} ; 1.4 \mathrm{mg} \cdot \mathrm{dm}^{-3} \mathrm{P}$; $1.0 \% \mathrm{OM} ; 5.5 \mathrm{CaCl} \mathrm{pH} ; 39.3 \% \mathrm{~V} ; 6.7 \% \mathrm{~m} ; 2.8 \mathrm{cmol} \cdot \mathrm{dm}^{-3} \mathrm{CEC}(\mathrm{T}) ; 1.2 \mathrm{cmol} \cdot \mathrm{dm}^{-3} \mathrm{CEC}(\mathrm{t}) ; 639.0 \mathrm{~g} \cdot \mathrm{kg}^{-1}$ sand; $38.0 \mathrm{~g} \cdot \mathrm{kg}^{-1}$ silt; $323 \mathrm{~g} \cdot \mathrm{kg}^{-1}$ clay.

The experiment used a randomized block design, with five treatments and four replicates. The treatments tested are shown in Table 1, and include four applications of effluent from a biodigester septic tank and one control with NPK fertilizer.

Table 1. Description of the treatments.

\begin{tabular}{lcc}
\hline Treatment & Description & Total applied \\
\hline T20 & 5 applications of 4 mm each over 10 days. & $20 \mathrm{~mm}$ \\
T16 & 4 applications of 4 mm each over 15 days. & $16 \mathrm{~mm}$ \\
T12 & 3 applications of 4 mm each over 20 days. & $12 \mathrm{~mm}$ \\
T8 & 2 applications of $4 \mathrm{~mm}$ each over 20 days. & $8 \mathrm{~mm}$ \\
T (NPK) & $60 \mathrm{kgha}^{-1}$ of $\mathrm{K}_{2} \mathrm{O}, 40 \mathrm{kgha}^{-1}$ of $\mathrm{P}_{2} \mathrm{O}_{5}$ and $20 \mathrm{kgha}^{-1}$ of $\mathrm{N}$. & - \\
\hline
\end{tabular}

The applications of effluent were distributed, with the first being performed 15 days after emergence (DAE) for all of the treatments, when the plants were at the V2 growth stage. The control was fertilized according to the recommendation for the crop (40 kg.ha- ${ }^{-1}$ of $\mathrm{P}_{2} \mathrm{O}_{5}$ at sowing); nitrogen and potassium applications were split into two applications: one half $\left(30 \mathrm{~kg} \cdot \mathrm{ha}^{-1}\right.$ of $\mathrm{K}_{2} \mathrm{O}$ and $10 \mathrm{~kg} \cdot \mathrm{ha}^{-1}$ of N$)$ at the V2 stage and another half at 30 DAE. The effluent tested was collected from the Vale Verde Settlemen Project $\left(48^{\circ} 59^{\prime} \mathrm{N}\right.$ and $\left.48^{\circ} 58^{\prime} \mathrm{W}\right)$, located $25 \mathrm{~km}$ from the seat of the municipality of 
of Gurupi/TO, Brazil. The chemical composition of the effluent is shown in Table 2.

Table 2. Chemical composition of the effluent collected in eight biodigester septic tanks at the Vale Verde settlement, municipality of Gurupi/TO, Brazil.

\begin{tabular}{ccccc}
\hline Parameter & Mean & Standard deviation & Heavy metal limit & Unit \\
\hline $\mathrm{Al}$ & 0.18 & 0.25 & - & $\mathrm{mg} \cdot \mathrm{kg}^{-1}$ \\
$\mathrm{~B}$ & 0.54 & 0.44 & - & $\mathrm{mg} \cdot \mathrm{kg}^{-1}$ \\
$\mathrm{Ba}$ & 0.06 & 0.02 & - & $\mathrm{mg} \cdot \mathrm{kg}^{-1}$ \\
$\mathrm{Ca}$ & 39.01 & 12.78 & - & $\mathrm{mg} \cdot \mathrm{kg}^{-1}$ \\
$\mathrm{Cd}$ & $\mathrm{Nd}$ & $\mathrm{nd}$ & 850 & $\mu \mathrm{g} \cdot \mathrm{kg}^{-1}$ \\
$\mathrm{Co}$ & $\mathrm{Nd}$ & $\mathrm{nd}$ & 840 & $\mu \mathrm{g} \cdot \mathrm{kg}^{-1}$ \\
$\mathrm{Cr}$ & 0.28 & 0.27 & 30000 & $\mu \mathrm{g} \cdot \mathrm{kg}^{-1}$ \\
$\mathrm{Cu}$ & 0.13 & 0.09 & 4300 & $\mathrm{mg} \cdot \mathrm{kg}^{-1}$ \\
$\mathrm{Fe}$ & 0.17 & 0.17 & - & $\mathrm{mg} \cdot \mathrm{kg}^{-1}$ \\
$\mathrm{~K}$ & 68.63 & 8.38 & - & $\mathrm{g} \cdot \mathrm{kg}^{-1}$ \\
$\mathrm{Mg}$ & 11.56 & 4.61 & - & $\mathrm{g} \cdot \mathrm{kg}^{-1}$ \\
$\mathrm{Mn}$ & 0.01 & 0.04 & - & $\mathrm{mg} \cdot \mathrm{kg}^{-1}$ \\
$\mathrm{Mo}$ & 0.72 & 0.59 & - & $\mathrm{g} \cdot \mathrm{kg}^{-1}$ \\
$\mathrm{Na}$ & 80.59 & 28.54 & - & $\mu \mathrm{g} \cdot \mathrm{kg}^{-1}$ \\
$\mathrm{Ni}$ & 0.12 & 0.09 & 310 & $\mathrm{~g} \cdot \mathrm{kg}^{-1}$ \\
$\mathrm{P}$ & 6.28 & 2.34 & - & $\mathrm{\mu g} \cdot \mathrm{kg}^{-1}$ \\
$\mathrm{~Pb}$ & 0.33 & 0.20 & 840 & $\mathrm{~g} \cdot \mathrm{kg}^{-1}$ \\
$\mathrm{~S}$ & 16.96 & 5.09 & - & $\mathrm{mg} \cdot \mathrm{kg}^{-1}$ \\
$\mathrm{Si}$ & 179.88 & 32.29 & - & $\mathrm{mg} \cdot \mathrm{kg}^{-1}$ \\
$\mathrm{Sr}$ & 1.88 & 1.00 & - & $\mathrm{mg} \cdot \mathrm{kg}^{-1}$ \\
$\mathrm{Ti}$ & 0.04 & 0.06 & $\mathrm{mg} \cdot \mathrm{kg}^{-1}$ \\
$\mathrm{~V}$ & 0.33 & 0.19 & - & $\mathrm{mg} \cdot \mathrm{kg}^{-1}$ \\
$\mathrm{Zn}$ & 0.07 & 0.05 & & -
\end{tabular}

The "BRS Pujante" cowpea cultivar was studied; it has indeterminate growth habits, semideterminate size, dry brown pods, and dry brown to evergreen beans. This cultivar stands out for providing shorter harvest periods and higher mean yields, which allows it to be planted in both rain-fed and irrigated systems (BRITO et al., 2012; SANTOS et al., 2008).

Each experimental unit comprised five $5 \mathrm{~m}$-long rows spaced $1 \mathrm{~m}$ apart with plants spaced $0.12 \mathrm{~m}$ apart. The second row was used as a plot for growth analysis and was subdivided into seven subplots to periodically sample the plants. The fourth row was used as a plot for agronomic variables.

The plants were sowed via the conventional planting system on March 17, 2009. Liming was performed based on soil analysis and according to the crop's requirement. The phytosanitary treatments used were those usually used for the crop and were applied when necessary. Irrigation was performed using a sprinkler system with a 65 -min watering interval, and a 6-mm water hose was used to irrigate the crop three times a week to maintain the soil at $65 \%-70 \%$ field capacity when rainfall declined.

Seven evaluations were performed for growth analysis, at 18, 28, 38, 48, 58, 68, and 78 DAE, in which three plants were evaluated per plot. The plants were placed in a forced-circulation oven at $70^{\circ} \mathrm{C}$ until they reached a constant weight. Next, they were weighed using scales with a precision of $0.001 \mathrm{~g}$ to 
determine dry weight (DW). Leaf area (LA) was calculated by determining the DW of ten disks and then using the ratio of leaf area to weight to calculate LA, according to the methods DAUGHTRY (1990). Growth analysis was performed according to the methods of BENINCASA (2003), and the following variables were analyzed: leaf area index (LAI), absolute growth rate (AGR), relative growth rate (RGR), and net assimilation rate (NAR).

The following agronomic characteristics were evaluated: grain weight of five pods (W5P) obtained using the mean grain weight of five pods; length of five pods (L5P) obtained using the mean grain length of five pods; number of grains of five pods (NG5P) obtained by counting the number of grains in five pods, plus mean grain weight from 5 pods GW5P. Further, the number of pods per plant (NPP) was the mean of the number of pods counted for five plants, and grain yield (YIELD) was determined after threshing the pods, cleaning the beans, correcting bean moisture content to $13 \%$, and converting yield to $\mathrm{kg} \cdot \mathrm{ha}^{-1}$.

The data were subjected to analysis of variance (ANOVA) using the $\mathrm{F}$ test at $5 \%$ probability. The means were grouped using Tukey's test at 5\% probability when a significant effect of the applied treatments was found; regression analysis was used in the case of a significant effect of time. The association between the means was evaluated using Pearson correlation; the independent variables were used for this correlation analysis. The statistical analyses were performed using SPSS, version 15.0 (IBM).

\section{RESULTS AND DISCUSSION}

There was a significant interaction $(\mathrm{P}<0.01)$ between time and the applied treatments for the DW variable, with a linear response for time (Figure $2-\mathrm{A}$ ). The highest growth rates were observed for the T12, T8, and NPK treatments, whereas the T20 and T16 treatments exhibited the lowest rates. 
Figure 2. Dry weight (A) and leaf area (B) of the cowpea plants fertilized with different doses of biodigester septic tank effluent plus a control with NPK fertilizer throughout the days after emergence. Significant $(\mathrm{P}<0.05)$ interaction between time and treatments; significant $(\mathrm{P}<0.01)$ regression models; vertical bars indicate standard deviation and asterisks in the horizontal axis indicate significant difference by Tukey's test $(\mathrm{P}<0.05)$ on the sampling date (Dry weight $\mathrm{cv}=$ $12 \%$; Leaf area $\mathrm{cv}=11 \%$ ).
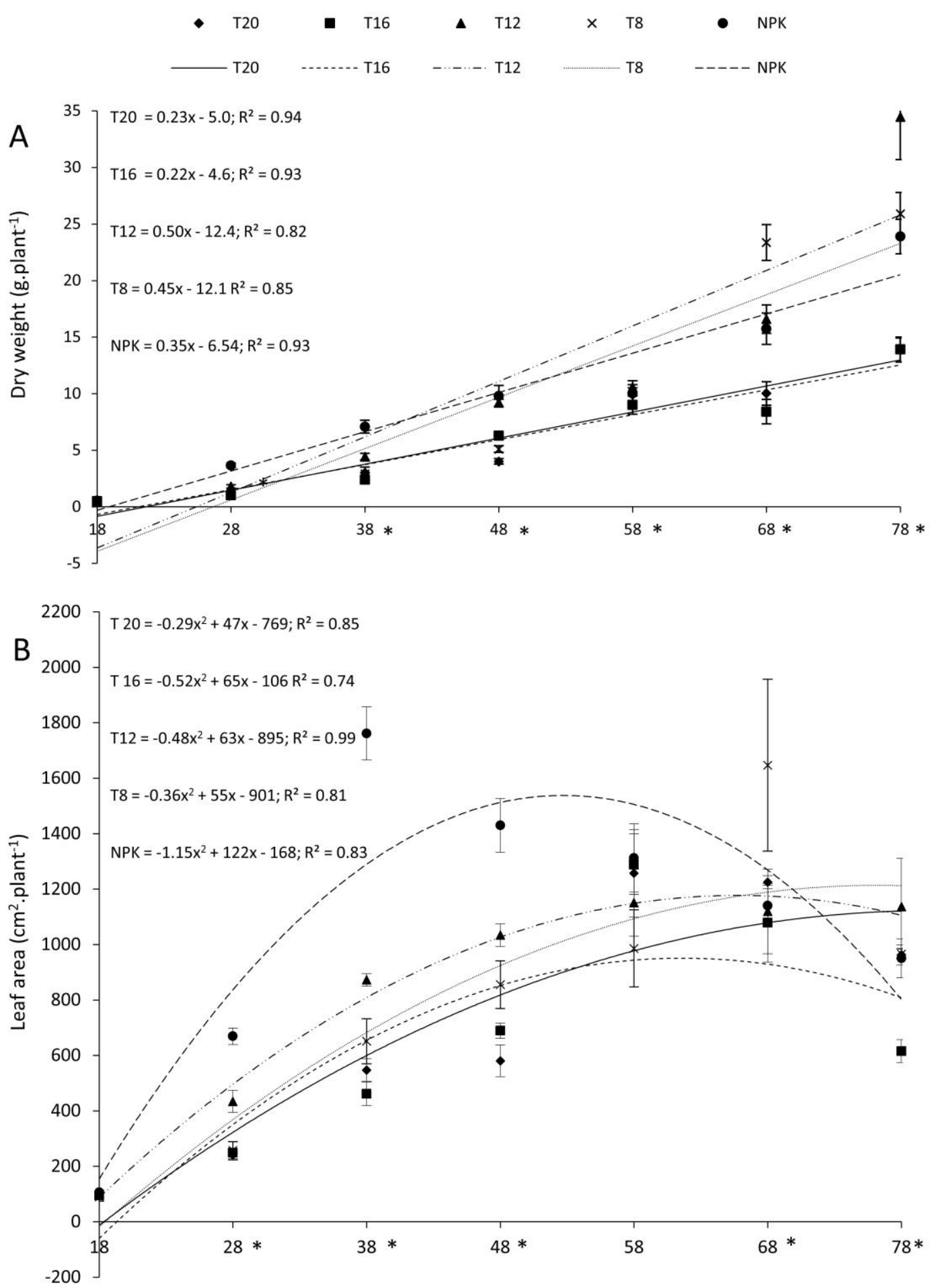

Days after emergence 
There was a significant difference in DW beginning at 28 DAE up to 58 DAE, the lowest DW values being observed for the T20 and T16 treatments. After 68 DAE, three distinct groups were formed. At 78 DAE the T12 treatment exhibited the highest DW, the NPK and T8 treatments comprised the group with intermediate DW, and the group with the lowest values was composed of the T16 and T20 treatments.

These results indicated that the accumulated DW tended to increase with a reduction in the dose of effluent; the doses of the T8 and T12 treatments had a response similar to that of the fertilized treatment. Lower accumulation of DW in the T16 and T20 treatments may have occurred because of nutritional disequilibrium problems caused by large quantities of nutrients available in the effluents (DUARTE et al., 2008; GLOAGUEN, 2007; VIEIRA, CASTILHOS and CASTILHOS, 2012).

Silva et al. (2009) found that cowpea plants responded negatively to increased salinity (a $69.10 \%$ decrease compared to the control treatment). Rebouças et al. (2010) found that an increase in the proportion of maturation pond effluent in the water supply for the fertigation of cowpea plants improved plant dry matter production; however, the effluent used by the authors had $5.5 \%$ of the calcium, $31.7 \%$ of the magnesium, $14.3 \%$ of the sodium, and $1 \%$ of the potassium of the effluent used in the present study (Table 2).

There was an interaction between time and treatment for the LA variable, with a fitted seconddegree polynomial model (Figure $2-\mathrm{B}$ ). There was increased expansion of LA until 58 DAE for the T16 treatment, 68 DAE for the T12 treatment, and 78 DAE for the T20 and T8 treatments; however, in the treatment with NPK fertilizer, LA exhibited higher expansion between 38 and 48 DAE.

This higher expansion of LA in the plants that received NPK fertilizer was caused by the rapid availability of minerals for the plants. According to Vieira, Castilhos and Castilhos, (2011), high mineralization observed in the NPK formulation was related to the nature of the N sources (urea), which, via urease, is quickly transformed into ammonia that becomes available to the plants. On the contrary, mineralization of organic matter occurs slowly, as the material continues to degrade. Thus, the use of effluents may delay the vegetative cycle, without necessarily compromising their productivity (SOUSA et al., 2006; SOUSA NETO et al., 2012).

At 28, 38, and 48 DAE, the mean LA was higher in the NPK treatment and at 68 DAE, it was higher in T8. At the end of the evaluations (78 DAE), there was a convergence of the LA values of the treatments, most likely due to the reproductive period, because cowpea tends to adjust its physiological variables to avoid loss in productivity (BORGES et al., 2012; LEITE; VIRGENS FILHO, 2004; SANTOS et al., 2011; SILVA et al., 2011).

Rebouças et al (2010) observed a similar response of cowpea ("Sempre Verde" cultivar) leaf area between treatment with doses of wastewater from treated sewage and treatment with mineral fertilizer. Souza Neto et al. (2012) analyzed the growth of herbaceous cotton and found that leaf area was affected by irrigation with wastewater at 15 and 30 days after planting compared with the chemical fertilizer of the control treatment.

There was a significant interaction between time and treatment for LAI, with the adjustable second-degree polynomial model (Figure 3 - A). In an effect similar to that seen for LA, the treatments using effluent as fertilizer led to increased expansion of LAI until 68 and 78 DAE, whereas the treatment using NPK fertilizer led to higher LAI between 38 and 48 DAE. This similar response to that of LA occurred because competition among the plants from each treatment was not high, which was evidenced by LAI not exceeding 1.75 . This indicated low competition between the plants for light, even in the treatment that exhibited greater LA expansion. 
Figure 3. Leaf area index (A) and absolute growth rate (B) of the cowpea plants fertilized with different doses of biodigester septic tank effluent, plus a control with NPK fertilizer throughout the days after emergence, farmed in Gurupi, TO, Brazil. Significant polynomial regression models $(\mathrm{P}<0.01)$; vertical bars indicate standard deviation and asterisks in the horizontal axis indicate significant difference by Tukey's test $(\mathrm{P}<0.05)$ on the sampling date (Leaf area index cv $=11 \%$; Absolute growth rate $\mathrm{cv}=14 \%$ ). Asterisks in the horizontal axis indicate significant difference by Tukey's test $(\mathrm{P}<0.05)$ on the sampling date (Relative growth rate $\mathrm{cv}=17 \%$; net assimilation rate $\mathrm{cv}=15 \%$ ).

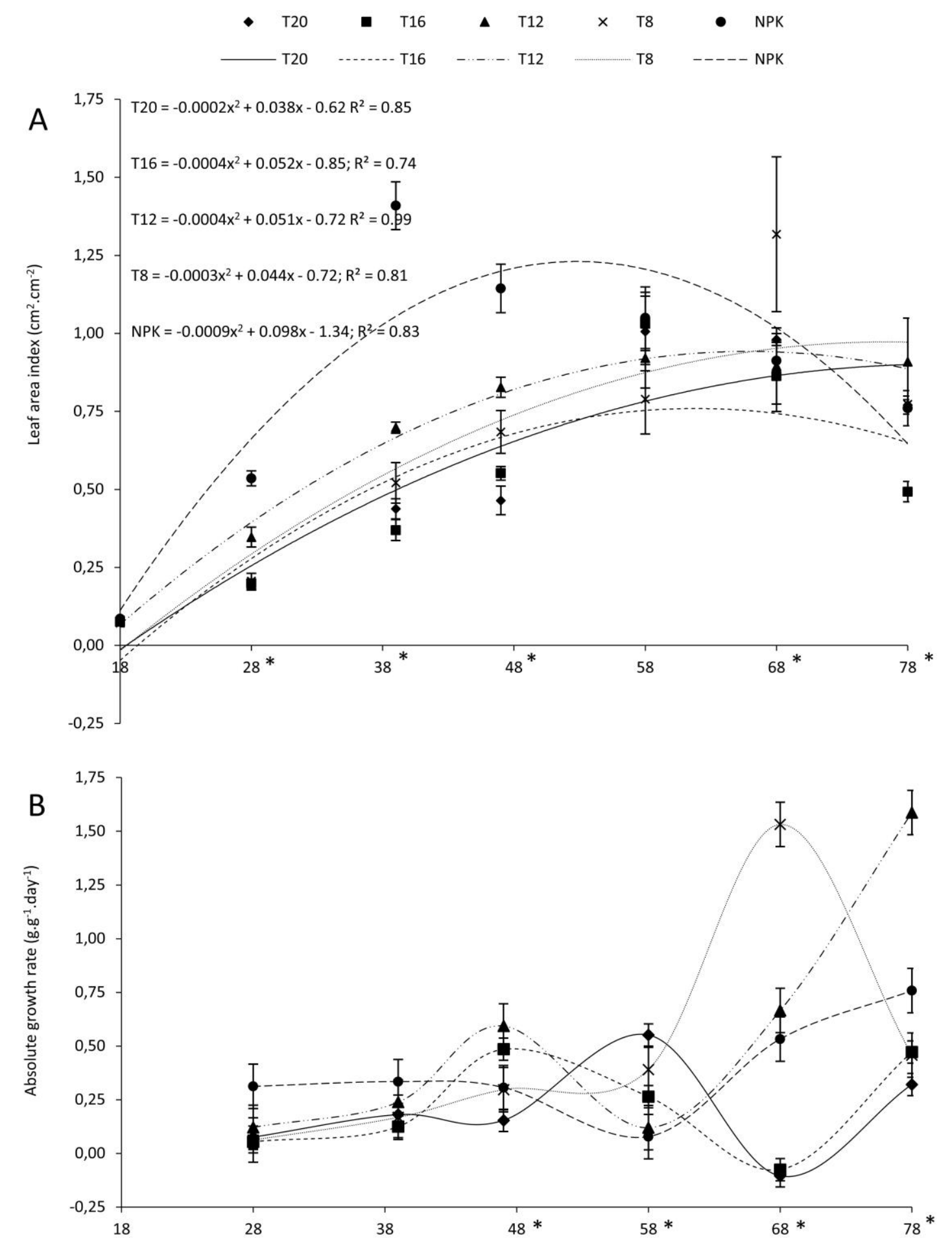

Days after emergence 
At 28, 38, and 48 DAE, the mean LAI was also higher in the treatment that received NPK, whereas at $68 \mathrm{DAE}$, only the T8 treatment group showed significantly higher values. At the end of the cycle, plants from all treatment groups exhibited similar LAI values. These results demonstrated that the delay in the vegetative cycle was a result of using wastewater, compared to the vegetative cycle when using mineral fertilizer, as also shown by Leite; Virgens Filho (2004) and Sousa et al. (2006). These authors observed that cowpea plants recovered after a period of stress in which a portion of the assimilates was converted into leaves to increase the uptake of solar radiation available during the recovery process.

There was no significant interaction between time and treatment for AGR. At 28, 38, and 48 DAE (Figure $3-\mathrm{B}$ ); however, the major differences were observed at 58, 68, and $78 \mathrm{DAE}$, when the plants were at the reproductive stage.

The plants that received $20 \mathrm{~mm}$ and $16 \mathrm{~mm}$ of biodigester septic tank effluent (T20 and T16) had similar responses with regard to AGR; the lowest values occurred at $68 \mathrm{DAE}$ and the highest values occurred at 78 DAE. With the NPK and T12 fertilizer applications, intermediate values of AGR were obtained at $68 \mathrm{DAE}$ and high values at 78 DAE. The T8 treatment exhibited the highest AGR value at 68 DAE, a different response from the other treatments.

AGR is related to the dry weight that a plant accumulates within a time interval (BENINCASA, 2003). The treatment using $8 \mathrm{~mm}$ of effluent led to higher AGR at 68 DAE, which indicated that this treatment caused dry weight accumulation during the plants' reproductive phase. The changes to the cowpea cycle were probably a measure to recover from stresses that the plant may have been under (LEITE; VIRGENS FILHO, 2004; LOPES et al., 2009; SANTOS et al., 2011, SANTOS et al., 2017). In addition, few negative AGR values were observed, which indicated low senescence of plant organs, probably a result of the low competition between the plants (LOPES et al., 2009), as observed for LAI (Figure $3-\mathrm{A}$ ).

Although third degree (or more) polynomial functions are not recommended to describe biological processes in plant development (SILVA et al., 2009), cubic and quadratic models were used to describe the response of RGR over time, based on the determination coefficient and significance of the fitted models (Figure $4-\mathrm{A}$ ). The T20, T16, and T8 treatments fitted the cubic function, whereas the T12 and NPK treatments fitted the quadratic function. 
Figure 4. Relative growth rate (RGR) (A) and net assimilation rate (NAR) of the cowpea plants fertilized with different doses of biodigester septic tank effluent, plus a control with NPK fertilizer throughout the days after emergence. Significant $(\mathrm{P}<0.05)$ interaction between time and treatments; significant $(\mathrm{P}<$ $0.01)$ linear regression models; vertical bars indicate standard deviation and.
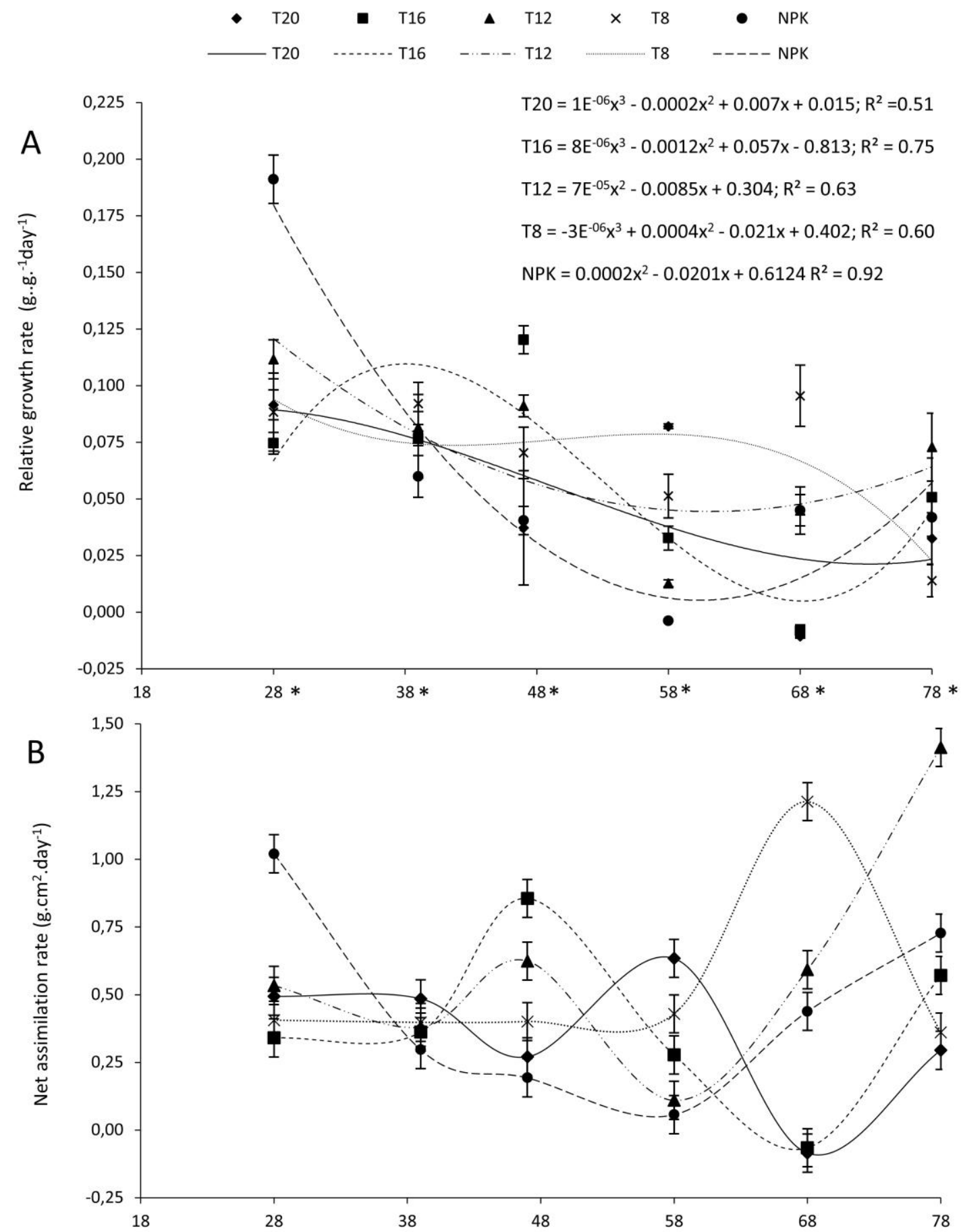

Days after emergence

At 28 DAE, only the NPK treatment differed from the others by exhibiting a high rate of accumulated dry weight starting at the vegetative stage; however, the means obtained with this treatment were lower at 38, 48, and $58 \mathrm{DAE}$, and matched the means of the other treatments at the end of the cycle. The behavior of RGR in the plants from he T16 reatment was also different from that in the other 
treatments: it increased until 38 DAE, decreased until 68 DAE, and increased again at 78 DAE. This indicated a greater relative accumulation of dry weight at the grain-filling phase. The behavior of RGR in the T20 and T12 treatments exhibited a similar trend over time, with values decreasing until the end of the cycle. In the T8 treatment, the values of AGR varied slightly over time. RGR values were similar in all treatments at the end of the cycle.

According to Benincasa (2003), RGR represents the increase in the dry weight of the plant or of any of its organs, compared to the dry weight at the onset of the observation period. The higher RGR observed in the treatment with chemical fertilizer during the vegetative stage may have occurred because the nutrients are more readily available in this type of fertilizer, thus favoring the plants' vegetative growth. In contrast, the treatment using $8 \mathrm{~mm}$ of effluent led to a more uniform AGR throughout the treatment, which indicates slower absorption of the nutrients throughout the cycle (BARBIERI et al., 2011).

The treatment with NPK exhibited the highest NAR (Figure $4-\mathrm{B}$ ) immediately at the start of the cycle, at 28 DAE, and the lowest rates were observed at 38, 48, and 58 DAE: NAR values rose again at the end of the reproductive period, at 68 and 78 DAE (third and second highest NAR, respectively). The behavior of NAR in the T8 treatment was similar to that of the AGR variable, with values remaining constant until $58 \mathrm{DAE}$, then increasing to the maximum at $68 \mathrm{DAE}$ and decreasing at the end of the cycle.

NAR represents the dry weight accumulated by the plant, considering the plants' leaf area and its previous dry weight. This variable thus represents biomass accumulation caused by increased net photosynthesis, which in turn is the result of greater fixation of light energy per unit of area (BARBIERI et al., 2011; BENINCASA 2003). The high value of NAR found at the onset of the cycle in the NPK treatment is another indication that nutrients are readily available in chemical fertilizers, whereas the T8 treatment, which had the best response to fertilization with the effluent, resulted in a more uniform NAR throughout the vegetative period, with a significant increase at the end of the cycle. Lopes et al. (2009), in an analysis of corn growth that compared conventional and no-tillage planting, obtained results similar to those in the T8 when no-tillage was used, and attributed the outcome to improved physical, chemical, and microbiological properties of the soil.

For the T20, T12, and T16 treatments, there was a significant variation in NAR values over time, similar to the response exhibited by AGR. This indicates nutritional disequilibrium because the increasing and decreasing NAR and AGR values reflect increasing and decreasing rates of dry weight accumulation throughout the cycle (BARBIERI et al., 2011; BENINCASA 2003).

Figure 5 shows the plants from each treatment at $38 \mathrm{DAE}$, where there is a visible difference between the treatment fertilized with NPK and the other treatments tested regarding plant appearance, namely a greater leaf area (Figure $2-B$ ). There was also a reduction in plant size due to increased dose of effluent, as can be seen in the DW, LA, and LAI variables of the plants (Figure 2, 3).

Figure 5. Cowpea plants fertilized with different doses of biodigester septic tank effluent, plus a control with NPK fertilizer at 38 days after emergence.

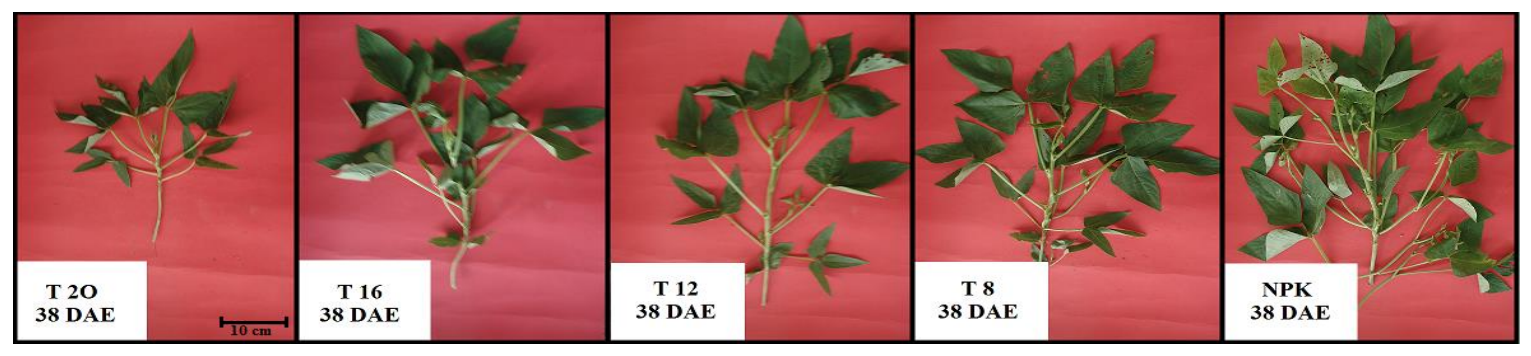


Table 3 shows the values related to agronomic characteristics. Fertilizing with NPK resulted in higher values of W5P; however, it was only significantly different from the W5P values of the T8 treatment group. There was no significant difference in L5P, which suggests that this variable is genetically determined and varies little variation with changes in the environment. NB5P varied between 48 beans in the treatment with NPK and 57 beans in the T8 treatment, i.e., a difference of 9 g. Fertilizing with NPK resulted in higher values of BW5P than in other treatments; however, it was only significantly different from values in the T16 treatment group. NPP was also higher in the plants from the NPK treatment and its decreasing trend with increase in effluent concentration is noteworthy.

Table 3. Weight from five pods (W5P), length of five pods (L5P), number of beans from five pods (NB5P), bean weight from 5 pods (BW5P), number of pods per plant (NPP), and bean yield (YIELD) of cowpea fertilized with different doses of biodigester septic tank effluent, plus a control with NPK fertilizer.

\begin{tabular}{ccccccc}
\hline Treatment & W5P & L5P & NB5P & BW5P & NPP & YIELD \\
\hline T20 & $14.6 \mathrm{ab}$ & $102 \mathrm{~ns}$ & $55 \mathrm{bc}$ & $12.3 \mathrm{ab}$ & $1.6 \mathrm{c}$ & $324 \mathrm{c}$ \\
T16 & $14.5 \mathrm{ab}$ & $102 \mathrm{~ns}$ & $51 \mathrm{ab}$ & $10.5 \mathrm{~b}$ & $2.1 \mathrm{bc}$ & $340 \mathrm{c}$ \\
T12 & $13.9 \mathrm{ab}$ & $105 \mathrm{~ns}$ & $51 \mathrm{ab}$ & $12.4 \mathrm{ab}$ & $2.2 \mathrm{~b}$ & $428 \mathrm{bc}$ \\
T8 & $12.3 \mathrm{~b}$ & $102 \mathrm{~ns}$ & $48 \mathrm{c}$ & $12.4 \mathrm{ab}$ & $2.6 \mathrm{a}$ & $530 \mathrm{ab}$ \\
NPK & $15.3 \mathrm{a}$ & $107 \mathrm{~ns}$ & $57 \mathrm{a}$ & $14.0 \mathrm{a}$ & $2.7 \mathrm{a}$ & $603 \mathrm{a}$ \\
\hline $\mathrm{cv}(\%)$ & 8.6 & 5.5 & 4.1 & 9.5 & 9.3 & 14.2
\end{tabular}

Means followed by the same letter in the column are equal using Tukey's test $(P<0.05)$. Means followed by the letters ns were not significant by $\mathrm{F}$ test $(P<0.05)$.

YIELD was significantly higher in the treatments with NPK fertilizer and the T8 dose of effluent (Table 3). However, the T8 treatment did not significantly differ from the T12 treatment. The yields of treatments with the T16 and T20 doses of effluent were significantly lower than those obtained with the NPK treatments and with the T8 dose of effluent, exhibiting on average a 39\% reduction in bean production.

A significant positive correlation was detected between YIELD and LA on all of the sampling dates (LA18, LA28, LA38, LA48, LA58, LA68, and LA78), as shown in Table 4. Among the variables related to YIELD, positive significant interactions only occurred between L5P and NB5P and between W5P and BW5P. Although the DW of the plants did not exhibit a direct correlation with grain yield on any of the sampling dates, this variable exhibited a correlation with NPP at 18, 28, 38, and 58 DAE, as well as with BW5P at 48 and 58 DAE and with W5P at 58 DAE (Table 3). 
Table 4. Pearson correlation coefficient between the variables; bean weight from five pods (W5P), length of five pods (L5P), number beans per five pods (NB5P), bean weight from 5 pods (BW5P), number of pods per plant (NPP), bean yield (YIELD), leaf area on all sampling dates (LA18, LA28, LA38, LA48, LA58, LA68, and LA78) and dry weight on all sampling dates (DW18, DW28, DW38, DW48, DW58, DW68, and DW78) of cowpea fertilized with different doses of biodigester septic tank effluent, plus a control with NPK fertilizer.

\begin{tabular}{|c|c|c|c|c|c|c|c|c|c|c|c|c|c|c|c|c|c|c|c|c|}
\hline & YIELD & W5P & L5P & NB5P & BW5P & NPP & LA18 & LA28 & LA38 & LA48 & LA58 & LA68 & LA78 & DW18 & DW28 & DW38 & DW48 & DW58 & DW68 & DW78 \\
\hline YIELD & 1.00 & $0.28^{\mathrm{ns}}$ & $0.85^{\mathrm{ns}}$ & $0.84^{\mathrm{ns}}$ & $0.15^{\mathrm{ns}}$ & $-0.49^{\mathrm{ns}}$ & $0.91 * *$ & $0.99 * *$ & $0.97^{* * *}$ & $1.00 * *$ & $0.95^{* *}$ & $0.99 * *$ & $0.99 * *$ & $-0.57^{\text {ns }}$ & $-0.47^{\mathrm{ns}}$ & $-0.32^{\mathrm{ns}}$ & $-0.14^{\mathrm{ns}}$ & $-0.09^{\text {ns }}$ & $0.51^{n s}$ & $0.82^{\mathrm{ns}}$ \\
\hline W5P & & 1.00 & $0.41^{\mathrm{ns}}$ & $0.55^{\mathrm{ns}}$ & $0.99 * *$ & $0.64^{\mathrm{ns}}$ & $0.42^{\mathrm{ns}}$ & $0.22^{\mathrm{ns}}$ & $0.19^{\mathrm{ns}}$ & $0.25^{\mathrm{ns}}$ & $0.29^{\mathrm{ns}}$ & $0.29^{\mathrm{ns}}$ & $0.30^{\mathrm{ns}}$ & $0.57^{\mathrm{ns}}$ & $0.63^{\mathrm{ns}}$ & $0.73^{\mathrm{ns}}$ & $0.83^{\mathrm{ns}}$ & $0.93 *$ & $0.86^{\mathrm{ns}}$ & $0.70^{\mathrm{ns}}$ \\
\hline L5P & & & 1.00 & $0.99 * *$ & $0.27^{\mathrm{ns}}$ & $-0.43^{\text {ns }}$ & $0.99^{* *}$ & $0.77^{\mathrm{ns}}$ & $0.70^{\mathrm{ns}}$ & $0.83^{\mathrm{ns}}$ & $0.96^{* * *}$ & $0.92 *$ & $0.90^{\mathrm{ns}}$ & $-0.50^{\text {ns }}$ & $-0.45^{\mathrm{ns}}$ & $-0.33^{\text {ns }}$ & $-0.16^{\text {ns }}$ & $0.06^{\mathrm{ns}}$ & $0.36^{\mathrm{ns}}$ & $0.63^{\text {ns }}$ \\
\hline NB5P & & & & 1.00 & $0.41^{\mathrm{ns}}$ & $-0.28^{\mathrm{ns}}$ & $0.98^{* *}$ & $0.77^{\mathrm{ns}}$ & $0.69^{\mathrm{ns}}$ & $0.83^{\mathrm{ns}}$ & $0.94 *$ & $0.90^{*}$ & $0.89 *$ & $-0.37^{\text {ns }}$ & $-0.30^{\mathrm{ns}}$ & $-0.17^{\mathrm{ns}}$ & $0.00^{\mathrm{ns}}$ & $0.21^{\mathrm{ns}}$ & $0.49^{\mathrm{ns}}$ & $0.72^{\mathrm{ns}}$ \\
\hline BW5P & & & & & 1.00 & $0.75^{\mathrm{ns}}$ & $0.27^{\mathrm{ns}}$ & $0.09^{\mathrm{ns}}$ & $0.08^{\mathrm{ns}}$ & $0.11^{\mathrm{ns}}$ & $0.15^{\mathrm{ns}}$ & $0.15^{\mathrm{ns}}$ & $0.16^{\mathrm{ns}}$ & $0.69^{\mathrm{ns}}$ & $0.74^{\mathrm{ns}}$ & $0.82^{\mathrm{ns}}$ & $0.90^{*}$ & $0.97 * *$ & $0.84^{\mathrm{ns}}$ & $0.62^{\mathrm{ns}}$ \\
\hline NPP & & & & & & 1.00 & $-0.43^{\text {ns }}$ & $-0.50^{\mathrm{ns}}$ & $-0.47^{\text {ns }}$ & $-0.51^{\text {ns }}$ & $-0.54^{\mathrm{ns}}$ & $-0.52^{\mathrm{ns}}$ & $0.51^{\mathrm{ns}}$ & $1.00^{* *}$ & $1.00 * *$ & $0.98 * *$ & $0.93 *$ & $0.88^{\mathrm{ns}}$ & $0.49^{\mathrm{ns}}$ & $0.09^{\text {ns }}$ \\
\hline LA18 & & & & & & & 1.00 & $0.85^{\mathrm{ns}}$ & $0.79^{\mathrm{ns}}$ & $0.90^{*}$ & $0.98^{* *}$ & $0.96^{* *}$ & $0.95^{*}$ & $-0.51^{\text {ns }}$ & $-0.44^{\text {ns }}$ & $-0.30^{\mathrm{ns}}$ & $-0.13^{\text {ns }}$ & $0.05^{\mathrm{ns}}$ & $0.44^{\mathrm{ns}}$ & $0.72^{\mathrm{ns}}$ \\
\hline LA28 & & & & & & & & 1.00 & $0.99^{* * *}$ & $0.99^{* *}$ & $0.91 *$ & $0.96^{* *}$ & $0.97 * *$ & $-0.58^{\text {ns }}$ & $-0.47^{\mathrm{ns}}$ & $-0.32^{\mathrm{ns}}$ & $-0.15^{\text {ns }}$ & $-0.15^{\text {ns }}$ & $0.51^{\mathrm{ns}}$ & $0.82^{\mathrm{ns}}$ \\
\hline LA38 & & & & & & & & & 1.00 & $0.97 *$ & $0.85^{*}$ & $0.92 *$ & $0.93^{\text {ns }}$ & $-0.55^{\text {ns }}$ & $-0.43^{\text {ns }}$ & $-0.29^{\mathrm{ns}}$ & $-0.12^{\mathrm{ns}}$ & $-0.15^{\text {ns }}$ & $0.53^{\mathrm{ns}}$ & $0.83^{\text {ns }}$ \\
\hline LA48 & & & & & & & & & & 1.00 & $0.95^{*}$ & $0.98 * *$ & $0.99 * *$ & $-0.59^{\text {ns }}$ & $-0.49^{\text {ns }}$ & $-0.34^{\mathrm{ns}}$ & $-0.17^{\text {ns }}$ & $-0.12^{\mathrm{ns}}$ & $0.49^{\mathrm{ns}}$ & $0.81^{\mathrm{ns}}$ \\
\hline LA58 & & & & & & & & & & & 1.00 & $0.98^{* *}$ & $0.98 * *$ & $-0.62^{\text {ns }}$ & $-0.54^{\mathrm{ns}}$ & $-0.41^{\mathrm{ns}}$ & $-0.23^{\text {ns }}$ & $-0.08^{\text {ns }}$ & $0.39^{\mathrm{ns}}$ & $0.71^{\text {ns }}$ \\
\hline LA68 & & & & & & & & & & & & 1.00 & $1.00 * *$ & $-0.60^{\text {ns }}$ & $-0.51^{\mathrm{ns}}$ & $-0.37^{\text {ns }}$ & $-0.19^{\text {ns }}$ & $-0.09^{\mathrm{ns}}$ & $0.45^{\mathrm{ns}}$ & $0.77^{\mathrm{ns}}$ \\
\hline LA78 & & & & & & & & & & & & & 1.00 & $-0.59^{\text {ns }}$ & $-0.50^{\mathrm{ns}}$ & $-0.35^{\mathrm{ns}}$ & $-0.17^{\text {ns }}$ & $-0.08^{\mathrm{ns}}$ & $0.47^{\mathrm{ns}}$ & $0.79^{\mathrm{ns}}$ \\
\hline DW18 & & & & & & & & & & & & & & 1.00 & $0.99 * *$ & $0.96 * *$ & $0.89 *$ & $0.83^{\text {ns }}$ & $0.41^{\mathrm{ns}}$ & $-0.01^{\mathrm{ns}}$ \\
\hline DW28 & & & & & & & & & & & & & & & 1.00 & $0.99 * *$ & $0.94 *$ & $0.86^{\mathrm{ns}}$ & $0.51^{\mathrm{ns}}$ & $0.11^{\mathrm{ns}}$ \\
\hline DW38 & & & & & & & & & & & & & & & & 1.00 & $0.98^{* *}$ & 0.91 ** & $0.65^{\mathrm{ns}}$ & $0.27^{\mathrm{ns}}$ \\
\hline DW48 & & & & & & & & & & & & & & & & & 1.00 & $0.94 * *$ & $0.77^{\mathrm{ns}}$ & $0.44^{\mathrm{ns}}$ \\
\hline DW58 & & & & & & & & & & & & & & & & & & 1.00 & $0.73^{\mathrm{ns}}$ & $0.43^{\text {ns }}$ \\
\hline DW68 & & & & & & & & & & & & & & & & & & & 1.00 & $0.91^{* * *}$ \\
\hline DW78 & & & & & & & & & & & & & & & & & & & & 1.00 \\
\hline
\end{tabular}

* significant at the level of $P \leq 0.05 ; * *$ significant at the level of $P \leq 0.01$ 
Oliveira et al. (2001) found a decline in pod and grain yields at higher doses of cattle manure in the presence of mineral fertilizer and attributed this response to the excess of nutrients provided to the crop. Ribeiro et al. (2012) evaluated the yield components of castor bean plants treated with various wastewater dilutions, and reported that replacing a portion of the chemical fertilizer with wastewater from treated domestic sewage produced satisfactory yields and reduced the consumption of high-quality water. Nobre et al. (2010) reported that effluent is as a good supplier of nutrients for sunflower plants.

Biodigester septic tank effluent is a good source of minerals for plants and a low-cost alternative to fertilizers, especially for small-scale farmers. However, using these residues involves physical, chemical, and microbiological changes that can positively or negatively affect the interaction between soil, plant, and nutrient. This occurs mainly because large quantities of nutrients are provided that can cause a nutritional imbalance and interfere with plant productivity (BLUM, MELFI and MONTES, 2012; NOBRE et al., 2010; SIMONETE et al., 2003; SOUSA et al., 2006; VIEIRA, CASTILHOS and CASTILHOS, 2011).

In this study, the use of biodigester septic tank effluent had an effect on plant development, and increasing the effluent dose reduced the performance of the variables related to growth analysis and grain yield. However, the treatment using $8 \mathrm{~mm}$ of effluent resulted in a productivity response similar to that elicited by the chemical fertilizer treatment, with the advantage of being an inexpensive source of nutrients.

\section{CONCLUSION}

An increase in the dose of biodigester septic tank effluent reduced the performance of the variables related to growth analysis and grain yield.

An 8-mm dose of biodigester septic tank effluent resulted in cowpea productivity similar to that obtained with the treatment with the NPK fertilizer recommended for the crop.

\section{REFERENCES}

BARBIERI, D. J. et al. Análise de crescimento de Bixa orellana L. sob efeito da inoculação micorrízica e adubação fosfatada. Revista Brasileira de Plantas Medicinais, v.13, n.2, p. 129-138, 2011. < http://dx.doi.org/10.1590/S1516-05722011000200002>

BENINCASA, M. M. P. Análise de Crescimento de Plantas, Noções Básicas. 2ed Jaboticabal: FUNEP, 2003. 41p.

BLUM, J.; MELFI, A. J.; MONTES, C. R. Nutrição mineral da cana-de-açúcar irrigada com efluente de esgoto. Pesquisa Agropecuária Brasileira, v.47, n.4, p. 593-602, 2012.

<http://dx.doi.org/10.1590/S0100-204X2012000400016.>

BORGES, P. R. S. et al. Distribuição de massa seca e rendimento de caupi inoculadas com rizóbio em Gurupi, TO. Revista Caatinga, v. 25, n. 1, p. 37-44, 2012.< https://www.redalyc.org/articulo.oa?id=237123860006>

BRITO, L. T. de L. et al. Produtividade da água de chuva em culturas de subsistência no Semiárido Pernambucano. Revista Engenharia Agrícola, 32(1): 102-109,2012.

<http://submission.scielo.br/index.php/eagri/article/view/41911/0> 
CETESB. Aplicação de biossólidos em áreas agrícolas: critérios para projeção e operação. Norma P4230. São Paulo, 1999.

CHAGAS JUNIOR, A. F. et al. Eficiência agronômica de estirpes de rizóbio inoculadas em caupi no Cerrado, Gurupi-TO. Revista Ciência Agronômica, v.41, p. 709-714, 2010. < https://www.redalyc.org/html/1953/195317568027/>

CONAMA - CONSELHO NACIONAL DO MEIO AMBIENTE - $\mathrm{N}^{\circ}$ 20, de 18 de junho de 1986, "Dispõe sobre a classificação das águas doces, salobras e salinas do Território Nacional" publicada no Diário Oficial da União de 30/07/1986.

DAUGHTRY, C. S. T. Direct measurement of canopy structure. In: GOEL, N. S.; NORMAN, J. M. (Eds.) Instrumentation for studying vegetation canopies for remote sensing in optical and thermal infrared regions. London: Harwood, 1990. p. 45-60.

DUARTE, A. S. et al. Efeitos da aplicação de efluente tratado no solo: $\mathrm{pH}$, matéria orgânica, fósforo e potássio. Revista Brasileira de Engenharia Agrícola e Ambiental, v.1, n.3, p. 302-310, 2008. < http://dx.doi.org/10.1590/S1415-43662008000300012.>

GLOAGUEN, T. V. et al. Soil solution chemistry of a Brazilian Oxisol irrigated with treated sewage effluent. Agricultural Water Management, v. 88, p.119-131, 2007.

< https://doi.org/10.1016/j.agwat.2006.10.018>

LEITE, M. de; VIRGENS FILHO, J. S. Produção de matéria seca em plantas de caupi (Vigna unguiculata (L.) Walp) submetidas a déficits hídricos. Publicatio UEPG: Ciências Exatas e da Terra, Ciências Agrárias e Engenharias, v.10, n. 1, p. 43-51, 2004. < http://dx.doi.org/10.5212/publicatio.v10i01.820>

LOPES, J. P. et al. Análise de crescimento e trocas gasosas na cultura de milho em plantio direto e convencional. Bragantia, v.68, n.4, p.839-848, 2009.

< http://dx.doi.org/10.1590/S0006-87052009000400003.>

NOBRE, R. G. et al. Produção do girassol sob diferentes lâminas com efluentes domésticos e adubação orgânica. Revista Brasileira de Engenharia Agrícola e Ambiental, v. 14, n.7, p.747-754, 2010. <http://www.scielo.br/pdf/rbeaa/v14n7/a10v14n7.pdf>

NOVAES, O. N. et al. Utilização de uma fossa séptica biodigestora para melhoria do saneamento rural e desenvolvimento da agricultura orgânica. (EMBRAPA de São Carlos. Circular Técnica, 46). São Carlos, 2002. 5p. < http://saneamento.cnpdia.embrapa.br/tecnologias/Comunicado_Tecnico-462002.pdf>

OLIVEIRA, A. P. et al. Rendimento de caupi cultivado com esterco bovino e adubo mineral.

Horticultura Brasileira, v.19, n. 1, p. 81-84, 2001.

<http://www.scielo.br/pdf/\%0D/hb/v19n1/v19n1a17.pdf>

OLSEN, J. E.; LARSEN, H. E. Bacterial decimation times in anaerobic digestions of animal slurries. Biological Wastes, v. 21, n. 3, p.153-68, 1987.<https://doi.org/10.1016/0269-7483(87)90121-2>

REBOUÇAS, J. R. L. et al. Crescimento do caupi irrigado com água residuária de esgoto doméstico tratado. Revista Caatinga, v.23, n. 1, p. 97-102, 2010. <

https://periodicos.ufersa.edu.br/index.php/caatinga/article/view/1506>

RIBEIRO, M. C. de F. et al. Crescimento e produtividade da mamoneira irrigada com diferentes diluições de esgoto doméstico tratado. Revista Brasileira de Engenharia Agrícola $e$ Ambiental, v. 16, n. 6, p. 639646, 2012. < http://dx.doi.org/10.1590/S1415-43662012000600008. 
SAN JOSÉ J. J. et al. Dry-matter partitioning and radiation-use efficiency in cowpea cultivars (Vigna unguiculata (L.) Walp. cvs TC-9-6 and M-28-6-6) during consecutive seasonal courses in the Orinoco llanos. The Journal of Agricultural Science, v.142, n. 2, p. 163-175, 2004. <https://doi.org/10.1017/S0021859604003922>

SANTOS, C. A. F. et al. Comportamento agronômico e qualidade culinária de caupi no Vale do São Francisco. Horticultura Brasileira, v. 26, n. 3, p. 404-408, 2008. < http://dx.doi.org/10.1590/S010205362008000300023.>

SANTOS, E. R. dos et al. Agronomic characteristics of lipoxygenase-free soybean introduced in low latitudes of the state of Tocantins. Núcleus, v.14, n.1,2017. < http://dx.doi.org/10.3738/1982.2278.2166>.

SANTOS, E. R. dos et al. Crescimento e teores de pigmentos foliares em caupi cultivado sob dois ambientes de luminosidade. Revista Caatinga, v. 24, n. 4 p. 14-19, 2011. < https://periodicos.ufersa.edu.br/index.php/caatinga/article/view/1619>

SILVA, A. R. da et al. Fertilidade do solo em agrofloresta após sucessão leguminosas: Consórcio mandioca e caupi, no Sul do Tocantins. Journal of Biotecnology and Biodiversity, v. 2, n. 2, p. 44-51, 2011. <file:///C:/Users/Elonha/Downloads/231-Texto\%20do\%20artigo-793-1-10-20120614.pdf>

SILVA, F. E. O. Desenvolvimento vegetativo do caupi irrigado com água salina em casa de vegetação. Caatinga, v. 22, n.3, p. 156-159, 2009.

< https://periodicos.ufersa.edu.br/index.php/caatinga/article/view/1089>

SIMONETE, M. A. et al. Efeito do lodo de esgoto em um Argissolo e no crescimento e nutrição de milho. Pesquisa Agropecuária Brasileira, v. 38, n. 10, p. 1187-1195, 2003. < http://dx.doi.org/10.1590/S0100204X2003001000008.>

SOUSA NETO, O. N. et al. Fertigação do algodoeiro utilizando efluente doméstico tratado. Revista Brasileira de Engenharia Agrícola e Ambiental, v. 16, n. 2, p. 200-208, 2012.< http://dx.doi.org/10.1590/S1415-43662012000200011>

SOUSA, J. T. de et al. Reuso de água residuária na produção de pimentão (Capsicum annuum L.). Revista Brasileira de Engenharia Agrícola $e$ Ambiental, v. 10, n. 1, p. 89-96, 2006.< http://www.scielo.br/pdf/\%0D/rbeaa/v10n1/v10n1a14.pdf>

TEIXEIRA, K. R. G. et al. Efeito da adição de lodo de curtume na fertilidade do solo, nodulação e rendimento de matéria seca do Caupi. Ciência e Agrotecnologia, v. 30, n. 6, p. 1071-1076, 2006. < http://dx.doi.org/10.1590/S1413-70542006000600004.>

VIEIRA, J. D.; CASTILHOS, D. D.; CASTILHOS. R. R. M. V. Atributos microbianos do solo após a adição de lodo anaeróbio da estação de tratamento de efluentes de parboilização do arroz. Revista Brasileira de Ciência do Solo, v.35, p. 543-550, 2011. < http://www.scielo.br/pdf/rbcs/v35n2/v35n2a23>

ZILLI, J. E. et al. Resposta do caupi à inoculação com estirpes de Bradyrhizobium recomendadas para soja. Revista Brasileira de Ciência do Solo, v. 35, p. 739-742, 2011. < http://dx.doi.org/10.1590/S010006832011000300009> 